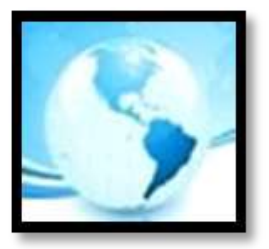

MALAYSIAN ONLINE JOURNAL OF

EDUCATIONAL MANAGEMENT

(MOJEM)

July 2019, VOLUME 7, ISSUE 3, 1 - 18

E-ISSN NO: $2289-4489$

\title{
THE TEACHING OF HIGHER ORDER THINKING SKILLS (HOTS) IN MALAYSIAN SCHOOLS: POLICY AND PRACTICES
}

Tiew Chia Chun \& Melissa Ng Lee Yen Binti Abdullah (PhD)

Institute of Educational studies,

University Science, Malaysia

Corresponding Author:

E-mail: johnaxtiew@gmail.com

\begin{abstract}
As a move towards educational transformation, the Ministry of Education (MOE) has established a policy on the teaching of Higher Order Thinking Skills (HOTS) and its practices are being emphasized throughout Malaysian education system. However, due to a lack of meta-analysis, the types of pedagogical practices used by teachers in enhancing students' HOTS in the local context is unclear. This study used a meta-analytical approach to fill in the gap in literature on the pedagogical practices of HOTS in Malaysian classrooms. A total of 32 empirical studies were included in the analyses. Therefore, this paper aims at synthesising the pedagogical practices of teaching HOTS among Malaysian teachers. The findings offered a synthesis of HOTS pedagogical practices employed by teachers in Malaysian schools, which could be categorised as practices that promote and practices that inhibit the teaching of HOTS. The synthesis revealed that some practices that promoted the teaching of HOTS were brainstorming, constructivist learning, inquiry teaching, thinking map, and problem-based learning whereas some practices that inhibited the teaching of HOTS were teacher-centered learning and teaching lower-order thinking skills.
\end{abstract}

Keywords: Teachers, Theory \& Practice, Higher Order Thinking Skills, Education, Malaysia. 


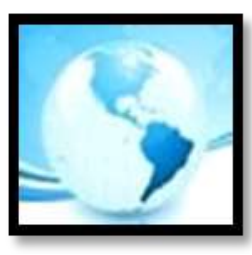

\section{MALAYSIAN ONLINE JOURNAL OF EDUCATIONAL MANAGEMENT (MOJEM)}

\section{INTRODUCTION}

The education system in Malaysia has undergone significant transformations over the past few decades. More importantly, the Education Act 1996 has been amended with the aim of providing support to meet the $21^{\text {st }}$ century challenges and to help Malaysia achieve reform objectives in pursuing world-class excellence in education (The HEAD Foundation, 2019; Azman, 1998). The Ministry of Education (MoE) has recently set a new policy and introduced some new inspirations, which aim to implement educational transformation and lead students towards the $21^{\text {st }}$ century learning. To strengthen the initiatives, MoE has begun the steps to reduce the emphasis on summative assessment, which refers to school or nationwide exams. According to the official statement by the Ministry, the school exams for lower primary pupils (Years One, Two, and Three) will be replaced by ClassroomBased Assessment that evaluates students' learning development (Hazlina \& Murniati, 2018; Sandhya \& Sheila, 2018). The ideas of removing the formal exams in the early years signifies that the Ministry has taken a step closer to promote meaningful and holistic learning of $21^{\text {st }}$ century skills. As the country's education is gradually moving away from examination-oriented system and rote learning, more emphasis is given to the development of students' Higher Order Thinking Skills (HOTS). HOTS questions have been infused into national curriculum since 2013. Clearly, teachers of all subjects are the key of transformation in developing students' HOTS during classroom learning.

Problem arises when teachers are asked to change the ways they teach in the classrooms because they have been trained to fit into the exam-oriented system. According to studies, certain teachers still face problems to ensure that HOTS is incorporated in their lessons. Rajendran (2008) stated that most teachers do not demonstrate sufficient preparedness towards the teaching of thinking skills. Tang and Tan (2015) also stated that professional training process does not facilitate the promotion of curious mind and analytic skills because teacher trainees often resort to the memorisation of facts and numbers. In the same vein, numerous studies found that the classroom learning and educational institutions placed too much focus on rote learning and teaching the content. Thus, it led to students' dependence on memorisation without the stimulation of analysis and synthesis of the precise meaning (e.g., Othman, Salleh, al-Edrus, \& Sulaiman, 2008; Rodzalan \& Saat, 2015; Živković, 2006). According to Pillay, Ainon Omar, Raja Nor Safinas Raja Harun, and Nurfilzah Zainal (2016), the analysis of their study revealed that the practices of most educators still rely heavily on conventional teaching approaches in Malaysian learning environment.

The issues mentioned above highlight an implementation gap which can be seen between the written policies and their implementation (Rajaendram, 2018). According to the UNESCO review (2013), teachers in Malaysia do not possess enough understanding and knowledge about the classroom practices that tally with the philosophy and objectives of the curriculum. It is crucial to investigate whether educators in Malaysia education contexts are prepared for the transformation towards the paradigm of $21^{\text {st }}$ century learning because there is a lack of empirical studies that examine teachers' practices of promoting HOTS in Malaysian classrooms. So, the uncertainty arises in terms of teachers' classrooms practices whether they are promoting or inhibiting HOTS among students. For that reason, there is a need to investigate the types of pedagogical practices employed by Malaysian teachers to understand more about what practices teachers have actually been using to promote students' development of HOTS in classrooms.

Therefore, the objectives of the current study were to investigate the pedagogical practices among teachers in teaching HOTS in the Malaysian education context. The following research questions guided the analysis:

RQ 1: What are the pedagogical practices that promote HOTS among students in Malaysian schools? RQ 2: What are the pedagogical practices that inhibit HOTS among students in Malaysian schools? 


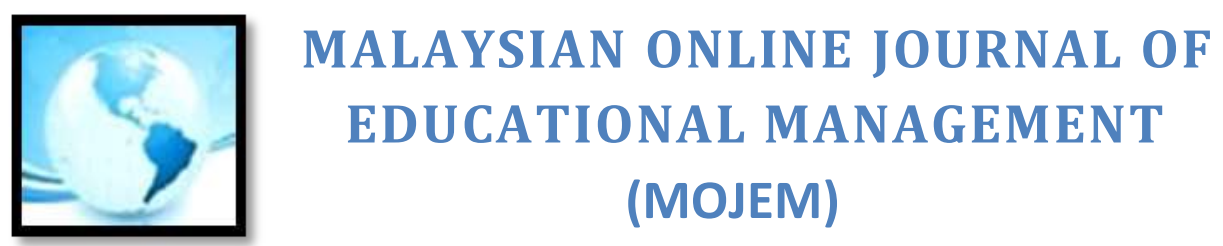

Policy on Teaching HOTS in Malaysian Schools

Looking at decades ago, numerous reports and policies have constantly formulated the Malaysian educational system (Chang, Morshidi, \& Dzulkifli, 2018). In 1998, Malaysia produced The National Philosophy of Education that emphasised the importance of developing holistic learners. Later in 2013, the Malaysia Education Blueprint 20132025 (MEB) was launched by the Ministry of Education. One of the six student aspirations highlighted in the MEB is the need for developing thinking skills. According to the MEB, Primary School Standard Curriculum or Kurikulum Standard Sekolah Rendah (KSSR) was launched to replace the existing KBSR. Generally, KSSR contains new content and learning standards which place greater emphasis on the development of holistic learners (Ministry of Education, 2013).

In 2017, the Ministry of Education has launched the Secondary School Standard Curriculum or Kurikulum Standard Sekolah Rendah (KSSM) and carried out a revised version of KSSR that aim to incorporate an equal distribution between knowledge and skills particularly higher order thinking and leadership skills. The revised version puts more focus on problem-based learning, process learning, and time-to-time assessments. Hence, the current policy clearly displays that the Malaysian education system is moving forward to creating learners who are able to use higher order thinking skills not only in the classrooms, but also in daily life. With that in mind, it is absolutely crucial for students to master higher order thinking so that they are able to grapple with the complexities and new challenges of the 21st century.

Critical thinking has been regarded as one of the most sought-after skills in contemporary industries and societies. Jalal (2017) pointed out that students should be exposed to critical thinking and learning skills in order to secure occupational opportunities in today's world. According to Hanif Hassan Ali Al Qassim (2017), it is necessary to integrate critical thinking skills into pedagogical teaching methodologies specifically for youths. On top of that, the current policy also increases the portion of HOTS questions. To encourage the implementation of the policy, at least $40 \%$ of the questions asked in Ujian Peperiksaan Sekolah Rendah (UPSR) also known as primary school achievement test will be based on the concepts of higher order thinking skills (HOTS) (Hassan, Rosli \& Zakaria, 2016). HOTS no longer just cover primary school but secondary school as well. HOTS based questions have covered 40\% in Pentaksiran Tingkatan Tiga (PT3), which is known as the standard assessment for the third-year students (Form Three) in secondary education. Meanwhile, it covers 50\% in Sijil Pelajaran Malaysia (SPM), which is also referred to the standard examination for the final year students (Form Five) in secondary education (Sivapakkiam, Fadzilah, Habsah, Umi, \& Rozita, 2016).

\section{THEORETICAL FRAMEWORK}

The theoretical framework (Figure 1) underpinned in the present study revolves around the current policy of Malaysia Education Blueprint (MEB) and the concept of attitude claimed under Rosenberg and Hovland's (1960) Hierarchical Model of Attitude. According to the education blueprint, the student aspirations are aligned with National Education Philosophy and one of the aspirations is to develop students' thinking skills. It is believed that the objectives postulated by the current policy to promote students' thinking skills exert changes to teachers' classroom practices in teaching HOTS. Therefore, it is important to see what teachers have done or practised in order to achieve the goal set by the Ministry.

Attitude is defined as an evaluative judgement towards a subject according to cognitive, affective, and behavioural aspects (Maio \& Haddock, 2010). In this study, the definition of attitude is only viewed as the behavioural component whereby teachers' behaviours towards the teaching of HOTS are investigated. The behavioural component describes the influences of attitude which change the ways an individual behaves (Cherry, 2018). In other words, it refers to the actions taken by teachers in order to teach HOTS in their lessons. On top of that, it also covers teachers' pedagogical practices used to teach HOTS in classrooms. 


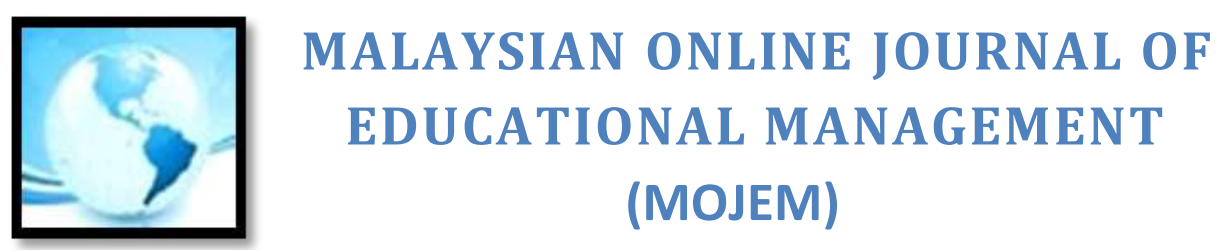

Since the aim of developing students into critical thinkers is reflected in the education blueprint, it signifies that teachers play a crucial role in achieving the target. Based on the theoretical framework (Figure 1), it indicates that teachers' behaviours can possibly affect their practices of teaching HOTS in classrooms. It is important to understand teachers' classroom practices of teaching HOTS because it can reflect the actual gap between the written policies and the practical situation of teaching HOTS. In short, the study was intended to investigate teachers' practices of teaching HOTS in primary, secondary, and tertiary education contexts.

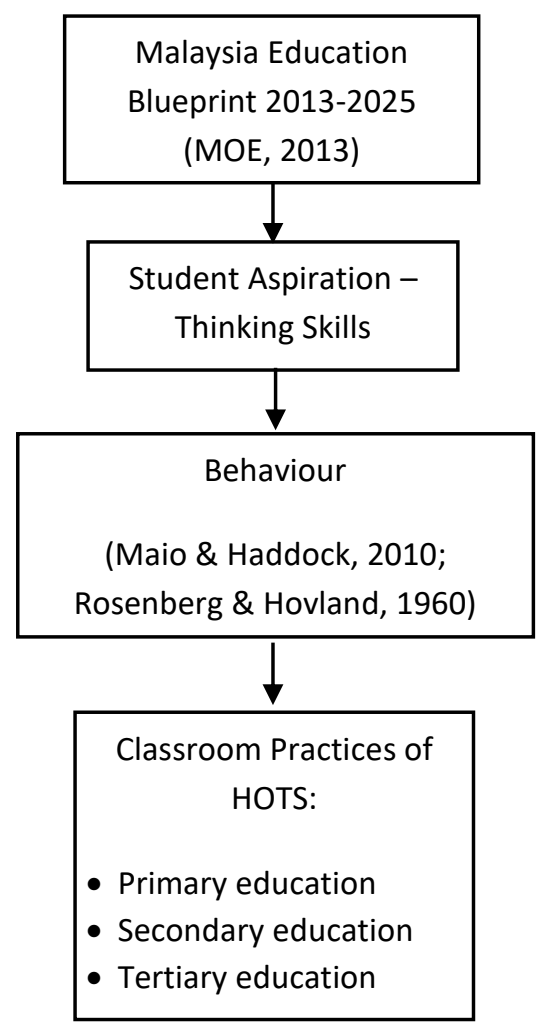

Figure 1. Theoretical Framework (Source: Adapted from Viennet and Pont, 2017, p. 21).

\section{METHOD}

This paper intended to display and synthesise information regarding teachers' pedagogical practices in teaching HOTS by making a meta-analysis of the past studies conducted. Meta-analytical approach functions to evaluate the evidence of many individual studies and come out with a summary of their results (Creswell, 2012). With the application of meta-analytical approach, findings discovered by other researchers pertaining to the teaching of HOTS in Malaysia were presented in the form of tables in this paper as shown below (Table $2-$ Table 5). In this study, the researchers applied meta-analytical approach with systematic steps for the literature search and the analysis of findings. The process took approximately three weeks to complete.

\section{Eligibility Criteria}

As the scope of the current study was set within the practices of teaching HOTS in Malaysian schools, the researchers only selected relevant texts according to a set of selection criteria. The criteria for the selection of the related studies were decided before searching the database. In addition, the criteria were also considered during 


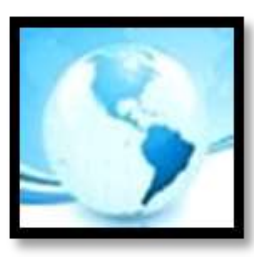

\section{MALAYSIAN ONLINE JOURNAL OF EDUCATIONAL MANAGEMENT (MOJEM)}

the screening of the titles, abstracts, and contents of the available texts. Google Scholar database was the prior search engine in choosing the relevant studies. It granted the researcher access for systematic and comprehensive lists related articles. Table 1 was provided to better illustrate the selection criteria of related studies.

\section{Data Collection Procedure}

In terms of the data collection procedure, the inclusion criteria for the analysis was open-accessed research articles, dissertation, and conference papers on the teaching of HOTS in Malaysia. This study covered quantitative, qualitative and mixed method studies published within the years of 2001 - 2018. Firstly, the core terms "teachers' practices of teaching higher order thinking skills OR HOTS" AND "Malaysia" were inserted in the search Engine, Google. As a result, the search action produced 802 results with 80 pages of 10 -studies per page. Next, all the available titles and abstracts of studies were skimmed through by the researchers. The researchers then excluded duplicate and foreign studies which did not fit into Malaysian education context. Studies that did not meet the aforementioned selection criteria (Table 1) were removed and a total of 32 empirical studies were chosen for the analysis. The researchers analysed and tabulated the characteristics of each literature and then assembled the most comprehensive dataset in the analysis. Lastly, the researcher explained the results and prepared a critical analysis to answer the research questions of the study.

Table 1

Criteria of selection

\begin{tabular}{ll}
\hline Criterion of selection & Criteria \\
\hline Scope of studies & Practices on teaching HOTS \\
Type of reference & Journal articles \\
& Dissertations \\
& Conference papers \\
Place of publication & Malaysia \\
Period of publication & $2001-2018$ \\
Access & Online \\
Research methodology & Quantitative \\
& Qualitative \\
\hline
\end{tabular}

\section{RESULT}

Researchers, educators, and other stakeholders have been working earnestly towards the goal of achieving better effectiveness of teaching HOTS in classrooms. To date, many studies have successfully yielded positive outcomes on the methods to teach HOTS in classrooms. This section presents several significant and effective practices promoting HOTS discussed by past studies within the scope of the teaching of HOTS in primary, secondary, and higher education across disciplines in Malaysia. In addition, the discussion also includes contrastive results as some researchers found teachers' practices to teach HOTS in classrooms. Some studies were carried out to investigate the practices that teachers actually apply in their daily lessons with the aim of enhancing students' content knowledge while developing their higher order thinking skills. Table 2, 3, 4, and 5 summarised key findings concerning teachers' pedagogical practices in teaching HOTS within Malaysian education context. Overall, the number of studies investigating teachers' practices in teaching HOTS has been increasing significantly since 2015. Over the period from 2001 to 2014, there were fewer studies conducted as compared to the period from 2015 to 2018. Hence, this implies that more emphasis has been placed on studies related to the teaching of HOTS in recent years. 


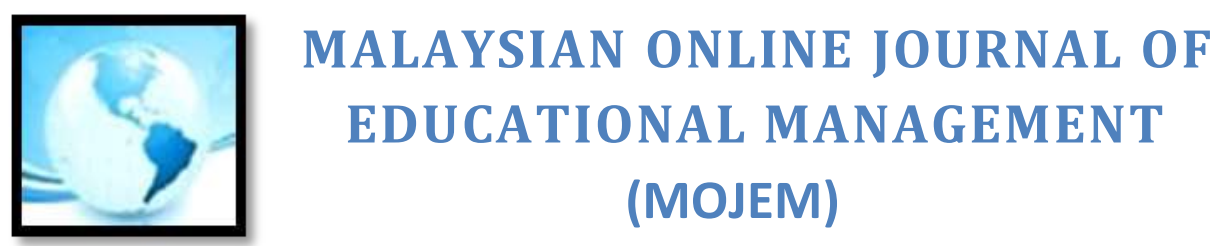

Teachers' Practices in Teaching HOTS

In this section, 32 studies were analysed in terms of teachers' practices in teaching HOTS is divided into several subcategories such as thinking map, constructivist learning, inquiry teaching, problem-based learning, low-level thinking, and teacher-centered learning. Table 2 was presented to illustrate the practices by Malaysian teachers that promote HOTS among their students whereas Table 3 displayed teachers' practices that inhibit the teaching of HOTS in Malaysian schools.

\section{- $\quad$ Teachers' Practices that Promote HOTS in Language Subjects}

Based on the meta-analysis shown in Table 2, it identifies the pedagogical practices employed by teachers who teach language subjects in classrooms. Looking at the analysis, inquiry teaching was recorded as the most frequently used pedagogical practices by language teachers, followed by thinking map, constructivist learning, brainstorming, and problem-based learning. The results from four studies indicate that English and Malay language teachers favoured the use of inquiry teaching to promote students' HOTS. The data gathered by Chew and Zul (2018) through questionnaire revealed that teachers preferred questioning because it could stimulate students' thinking in the classrooms. Ainon, Haniff, and Goh (2016) employed a qualitative research to explore how teachers implemented thinking maps in i-Think programme in their ESL lessons. Based on the observations, the finding revealed that the teacher allocated students into groups to stimulate discussion and interaction in completing the questions in the circle map. Throughout the process, students were also able to generate ideas and justification for their answers. The positive effect of using thinking maps to enhance HOTS is also evident in another study by Ainon and Intan (2016). With the help of thinking map and Reader-Response strategy in literature class, teachers facilitated students' process in producing ideas and made them think about the texts critically. Based on the analysis, it is proven that the thinking map can be an effective way to develop students' HOTS.

Secondly, the analysis continues with constructivist learning as the most preferred practices in promoting HOTS in English lessons. Social constructivism places priority on the notion of learning through social interaction and cooperation (Brown, 2007). To encourage collaboration among students, teachers allocate time for group discussion. When students are engaged in discussion, they get to stimulate their thinking skills because they are required to contribute ideas and opinions (Charanjit et al., 2018). This notion of enhancing HOTS through collaboration is also emphasised by other studies (Zainudin et al., 2018; Mohd \& Ahmad, 2017; Soo et al., 2015; Zuraina, 2009). Discussion is necessary to facilitate good cooperation among students. For that reason, the researcher discovers that teachers conducted classroom and online discussion to increase students' collaboration and thinking ability (Soo et al., 2015).

The analysis also displays the use of brainstorming among language teachers to promote students' HOTS (Malini et al., 2017; Mohd et al., 2016; Chiew et al., 2016). When students are engaged in brainstorming activities, there is an opportunity for them to stimulate own thoughts in generating ideas. In this way, students get to come out with more than one idea or diverse their thoughts for the task assigned. Lastly, another two studies showed that English teachers employed inquiry teaching by questioning students and encouraging them to make reflection (Charanjit et al., 2018; Chiew et al., 2016). At last, it is rare to see language teachers applied problem-based learning because only one study revealed the use of problem-based teaching among teachers to promote students' HOTS in classrooms (Mohd et al., 2016). 


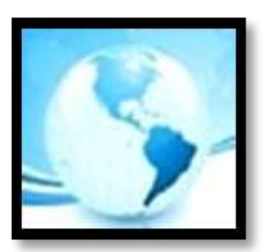

Table 2

Teaching Practices that Promote HOTS in Language Subject

\begin{tabular}{|c|c|c|c|c|}
\hline Author(s) & Subject(s) & Research Method & Techniques & Practices \\
\hline $\begin{array}{l}\text { Ainon \& } \\
\text { Intan (2016) }\end{array}$ & $\begin{array}{l}\text { - English } \\
\text { Language (ESL) }\end{array}$ & $\begin{array}{l}\text { - Qualitative (case study) } \\
\text { - Three teachers } \\
\text { - Structured interview and } \\
\text { observation }\end{array}$ & $\begin{array}{l}\text { - Utilised thinking maps and } \\
\text { Reader-Response strategy. }\end{array}$ & - Thinking map \\
\hline $\begin{array}{l}\text { Ainon, } \\
\text { Haniff, \& } \\
\text { Goh (2016) }\end{array}$ & $\begin{array}{l}\text { English } \\
\text { Language } \\
\text { (ESL) }\end{array}$ & $\begin{array}{l}\text { - Qualitative (case study) } \\
\text { - Five teachers } \\
\text { - Structured interview and } \\
\text { observation }\end{array}$ & $\begin{array}{l}\text { - Applied i-Think mind-maps. } \\
\text { - Encouraged discussion, } \\
\text { presentation of work, } \\
\text { justification of answers, and } \\
\text { generation of ideas. }\end{array}$ & $\begin{array}{l}\text { - Thinking map } \\
\text { - Constructivist } \\
\text { learning }\end{array}$ \\
\hline $\begin{array}{l}\text { Charanjit et } \\
\text { al (2018) }\end{array}$ & $\begin{array}{l}\text { - English } \\
\text { Language (ESL) }\end{array}$ & $\begin{array}{l}\text { - Qualitative } \\
\text { - Two teachers and } 45 \\
\text { secondary students } \\
\text { - Observation, interview, } \\
\text { and document analysis }\end{array}$ & $\begin{array}{l}\text { - Used graphic organisers and } \\
\text { questioning. }\end{array}$ & $\begin{array}{l}\text { - Thinking map } \\
\text { - Inquiry teaching }\end{array}$ \\
\hline $\begin{array}{l}\text { Malini et al } \\
\text { (2017) }\end{array}$ & $\begin{array}{l}\text { - English } \\
\text { Language (ESL) }\end{array}$ & $\begin{array}{l}\text { - Mixed methods } \\
\text { - } 40 \text { ESL lecturers } \\
\text { - Questionnaire and semi- } \\
\text { structured interview }\end{array}$ & $\begin{array}{l}\text { Employed brainstorming and } \\
\text { problem-solving approach. }\end{array}$ & - Brainstorming \\
\hline $\begin{array}{l}\text { Soo et al } \\
(2015)\end{array}$ & $\begin{array}{l}\text { - English } \\
\text { Language (ESL) }\end{array}$ & $\begin{array}{l}\text { - Mixed methods (quasi- } \\
\text { experiment) } \\
\text { - } 30 \text { undergraduates } \\
\text { - Treatment and interview }\end{array}$ & $\begin{array}{l}\text { - Applied classroom and online } \\
\text { discussion. }\end{array}$ & $\begin{array}{l}\text { - Constructivist } \\
\text { learning }\end{array}$ \\
\hline $\begin{array}{l}\text { Chew \& Zul } \\
\text { (2018) }\end{array}$ & - Malay Language & $\begin{array}{l}\text { - Quantitative } \\
\text { - } 90 \text { primary students } \\
\text { - Questionnaire }\end{array}$ & - Applied questioning technique. & - Inquiry teaching \\
\hline $\begin{array}{l}\text { Chew \& } \\
\text { Shashipriya } \\
\text { (2014) }\end{array}$ & $\begin{array}{l}\text { - Malay Language } \\
\text { (literature) }\end{array}$ & $\begin{array}{l}\text { - Quantitative } \\
\text { - } 40 \text { teachers and } 120 \\
\text { students } \\
\text { - Questionnaire }\end{array}$ & $\begin{array}{l}\text { - Encouraged students to ask } \\
\text { questions. }\end{array}$ & - Inquiry teaching \\
\hline $\begin{array}{l}\text { Mohd et al } \\
(2016)\end{array}$ & $\begin{array}{l}\text { - Arabic } \\
\text { Language }\end{array}$ & $\begin{array}{l}\text { - Quantitative } \\
\text { - } 30 \text { primary teachers } \\
\text { - Questionnaire }\end{array}$ & $\begin{array}{l}\text { - Used various approaches of } \\
\text { problem-solving and } \\
\text { generating ideas. }\end{array}$ & $\begin{array}{l}\text { - Problem-based } \\
\text { learning } \\
\text { - Brainstorming }\end{array}$ \\
\hline
\end{tabular}




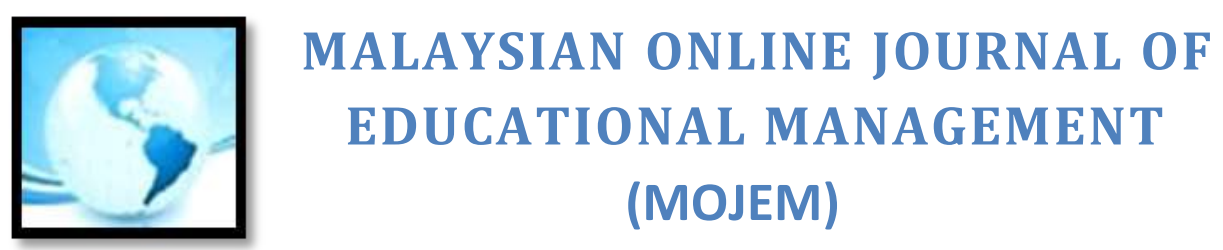

\section{- Teachers' Practices that Promote HOTS in Mathematics and Science}

When it comes to developing HOTS in mathematics and science classrooms, there were three types of practices used namely thinking map, constructivist learning, and problem-based learning. Based on the analysis in Table 3, it can be said that mathematics and science teachers favoured problem-based learning and constructivist learning when promoting HOTS among students in classrooms. When teachers apply problem-based learning in classroom, students are given more opportunities to think about the problems critically and come out with appropriate solutions to resolve the problems (Tajularipin et al., 2017; Tan \& Mohammad, 2014).

Tan and Mohammad (2014) realised that students' active learning, thinking, and questioning were stimulated through the use of problem-based learning in science lessons. The notion of enhancing thinking through problembased learning is supported by the qualitative research of Tajularipin et al. (2017). The researchers obtained responses from the participants, which explained that problem-solving activities encouraged students' use of HOTS specifically creativity.

Next, Kho, and Jamalludin (2015) confirmed that socio-collaborative learning environment gave great impacts on students' HOTS in learning chemistry. By engaging in game-based learning tasks, students got to stimulate their thinking skills in a constructive setting. Similarly, a study by Zaleha et al. (2016) also discovered that students' critical thinking could be developed through cooperative learning. Lastly, there is only one study proves the practice of using thinking map to develop HOTS in mathematics classrooms. Abdul et al. (2017) discovered that mathematics teachers occasionally employed i-Think mind map to stimulate students' HOTS in their classrooms.

Table 3

Teaching Practices that Promote HOTS in Mathematics and Science

\begin{tabular}{|c|c|c|c|c|}
\hline Author(s) & Subject(s) & Research Method & Techniques & Practices \\
\hline $\begin{array}{l}\text { Abdul et al., } \\
\text { (2017) }\end{array}$ & - Mathematics & $\begin{array}{l}\text { - Quantitative } \\
\text { - } 196 \text { mathematics } \\
\text { teachers } \\
\text { - Questionnaire }\end{array}$ & $\begin{array}{l}\text { - Applied the concepts of HOTS } \\
\text { with the reference to content } \\
\text { knowledge of mathematics. } \\
\text { - Occasional use of i-Think mind- } \\
\text { map. }\end{array}$ & - Thinking map \\
\hline $\begin{array}{l}\text { Zaleha et al., } \\
(2016)\end{array}$ & - Mathematics & $\begin{array}{l}\text { - Qualitative } \\
\text { - } 35 \text { pre-service teachers } \\
\text { - Open-ended } \\
\text { questionnaire }\end{array}$ & $\begin{array}{l}\text { - Enhanced critical thinking } \\
\text { through student-centered } \\
\text { learning, active learning, } \\
\text { cooperative learning, and } \\
\text { mastery learning. }\end{array}$ & $\begin{array}{l}\text { - Constructivist } \\
\text { learning }\end{array}$ \\
\hline $\begin{array}{l}\text { Kho \& } \\
\text { Jamalludin } \\
(2015)\end{array}$ & - Chemistry & $\begin{array}{l}\text { - Quantitative } \\
\text { - } 23 \text { secondary students } \\
\text { - Pre and post test }\end{array}$ & $\begin{array}{l}\text { - Assigned game-based learning } \\
\text { tasks and used socio- } \\
\text { collaborative learning } \\
\text { environment. }\end{array}$ & $\begin{array}{l}\text { - Constructivist } \\
\text { learning }\end{array}$ \\
\hline $\begin{array}{l}\text { Tan \& } \\
\text { Mohammad } \\
(2014)\end{array}$ & - Science & $\begin{array}{l}\text { - Qualitative } \\
\text { - One teacher and } 17 \\
\text { students } \\
\text { - Observation }\end{array}$ & $\begin{array}{l}\text { - Conducted problem-based } \\
\text { learning in science lessons. }\end{array}$ & $\begin{array}{l}\text { - Problem-based } \\
\text { learning }\end{array}$ \\
\hline
\end{tabular}




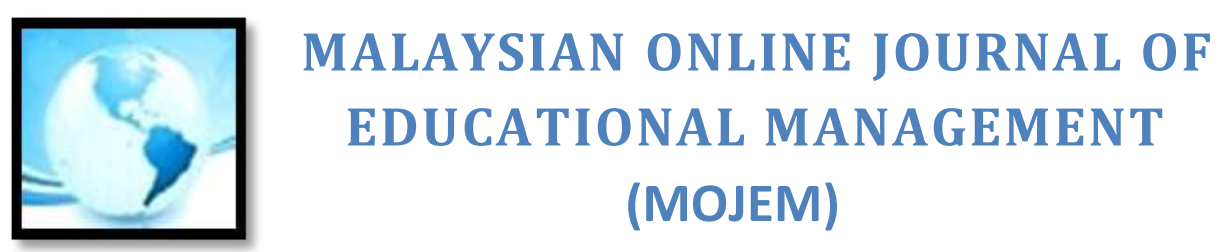

\section{- Teachers' Practices that Promote HOTS in Other Subjects}

In this section, the analysis (Table 4) indicates the pedagogical practices of promoting HOTS employed by teachers from other subjects including history, social science, Islamic studies, vocational, technical, and polytechnic studies, Malay, and so on. The analysis shows that teachers who teach other subjects preferred inquiry teaching as the highest number of practices to promote HOTS in their classrooms, followed by problem-based learning, brainstorming, constructivist learning, and thinking map. Four studies above show that teachers are keen on using questioning approach to enhance students' HOTS. With the use of questioning in class, students are offered more opportunity to generate thoughts and provide justification for their answers (Ainon et al., 2016; Awg Kasmurie et al., 2010). In 2010, Awg Kasmurie, Abdul Razak Ahmad, and Ahmad Ali Seman proved the effectiveness of inquiry teaching to enhance critical thinking in history lessons was high. Other than inquiry teaching, studies also show that teachers who teach subjects other than mathematics, science, and English applied problem-based learning for students' development of HOTS. Based on the result of a mixed method study, Jerome, Lee, \& Ting (2017) discovered that lecturers used problem-based learning as one of the instructional strategies to develop undergraduates' HOTS.

The result of the study agrees with a study done by Siti (2012) which stated that problem-solving method played an essential role in developing HOTS among students who underwent polytechnic courses. Another study also supports the application of problem-based learning to stimulate thinking skills among secondary students from various disciplines. (Rahil et al., 2004). As brainstorming is regarded as one of the effective practices in promoting HOTS, the analysis in this section consists of two studies. According to Zainudin et al. (2018), the majority of respondents included the use of brainstorming activities because it could stimulate students' thinking skills. The use of brainstorming in students' learning of HOTS can also be seen among lecturers who taught polytechnic courses (Siti, 2012). Lastly, Mohd, Mohd, \& Engku (2017) revealed that teachers in Islamic education employed constructivist learning such as group work to promote students' growth of HOTS in classrooms.

Table 4

Teaching Practices that Promote HOTS in Other Subjects

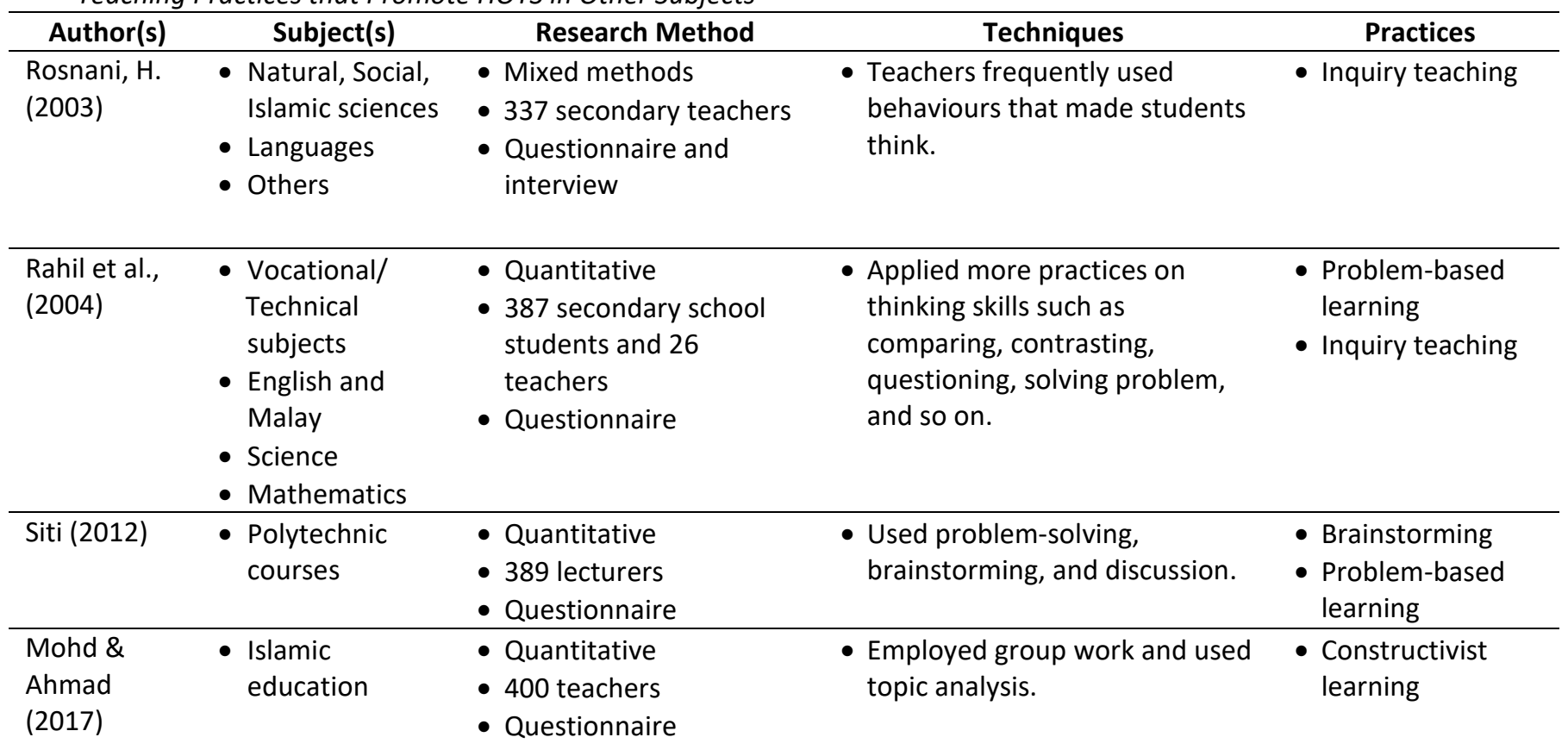




\begin{tabular}{|c|c|c|c|c|}
\hline $\begin{array}{l}\text { Awg } \\
\text { Kasmurie et } \\
\text { al. ,(2010) }\end{array}$ & - History & $\begin{array}{l}\text { - Quantitative (quasi- } \\
\text { experiment) } \\
\text { - } 41 \text { students (EG) and } 42 \\
\text { students (CG) } \\
\text { - Pre and post survey }\end{array}$ & $\begin{array}{l}\text { - Inquiry teaching enhanced } \\
\text { students' critical thinking in } \\
\text { History subject effectively. }\end{array}$ & - Inquiry teaching \\
\hline $\begin{array}{l}\text { Jerome, Lee, } \\
\& \text { Ting (2017) }\end{array}$ & - Unspecified & $\begin{array}{l}\text { - Mixed methods } \\
\text { - } 500 \text { students } \\
\text { - Questionnaire and } \\
\text { interview } \\
\end{array}$ & $\begin{array}{l}\text { - Applied discussion, PBL, } \\
\text { scaffolding, reflection, concept } \\
\text { mapping, case study, and } \\
\text { metacognition. }\end{array}$ & $\begin{array}{l}\text { - Thinking map } \\
\text { - Problem-based } \\
\text { learning }\end{array}$ \\
\hline $\begin{array}{l}\text { Zainudin et } \\
\text { al., (2018) }\end{array}$ & - Unspecified & $\begin{array}{l}\text { - Qualitative } \\
\text { - Seven primary teachers } \\
\text { - Structured interview }\end{array}$ & $\begin{array}{l}\text { - Applied 'questioning and } \\
\text { answering', brainstorming, } \\
\text { discussion, practical tasks, and } \\
\text { learning examples. }\end{array}$ & $\begin{array}{l}\text { - Brainstorming } \\
\text { - Inquiry teaching }\end{array}$ \\
\hline
\end{tabular}

\section{- Teaching of Low-Level Thinking}

In this section, the analysis depicts that teachers only teach lower-order thinking skills (LOTS) to students in Malaysian schools. It looks like teachers are not keen on applying strategies that develop HOTS (DeWitt et al., 2016). Table 5 was included to explain the practices that inhibit the teaching of HOTS among Malaysian teachers. A few studies obtained a similar result showing questions asked by teachers were of mainly lower order thinking. Azian, Fauziah, Noor, and Norhanim (2017) conducted a study which aims to obtain insights related to the teaching of HOTS in L2 classrooms. Each of the twenty teachers was chosen as the sample for the one-session observation. Result shows that ESL teachers tended to use verbs that only fostered low level thinking when teaching in classes. Similarly, the finding can be seen in Wan's and Shamilati's (2018). Generally, although teachers applied questioning approach in classes, yet most questions were of low level which only triggered recalling, short answers, and memorisation. Khairon, Hanita, Fauziah, and Azian (2017) realised that ESL teachers only applied display questions which required students to answer in one-word or short phrase. Consequently, it did not exert positive effects in developing students' HOTS.

\section{- $\quad$ Teacher-Centered Learning}

Based on the analysis (Table 5) on teachers' practices that inhibit the teaching of HOTS in classrooms, a few studies highlight that teachers still tend to conduct teacher-centered learning in classrooms. Teachers chose to teach students to answer exam questions rather than teaching thinking skills (Rajendran, 2001). Observation data revealed that science teachers chose to provide answers to the questions and investigations (Bavani et al., 2016). The finding is corroborated with the study conducted by DeWitt et al. (2016) which concludes that teachers prefer offering explanation without letting students think on their own. 


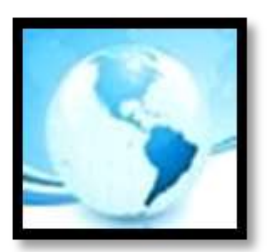

Table 5

Teaching Practices that Inhibit HOTS

\begin{tabular}{|c|c|c|c|c|}
\hline Author(s) & Subject(s) & Research Method & Techniques & Practices \\
\hline $\begin{array}{l}\text { Rajendran } \\
\text { (2001) }\end{array}$ & $\begin{array}{l}\text { - Malay Language } \\
\text { - English } \\
\text { Language }\end{array}$ & $\begin{array}{l}\text { - } \text { Mixed methods } \\
\text { - } 104 \text { teachers } \\
\text { - Interview, questionnaire, } \\
\text { observation }\end{array}$ & $\begin{array}{l}\text { - Teachers perceived to have } \\
\text { inadequate HOTS } \\
\text { pedagogical skills. } \\
\text { - Rather prepared students for } \\
\text { exams. }\end{array}$ & $\begin{array}{l}\text { Teacher- } \\
\text { centered } \\
\text { learning }\end{array}$ \\
\hline $\begin{array}{l}\text { Arlina \& } \\
\text { Melor (2014) }\end{array}$ & $\begin{array}{l}\text { - English } \\
\text { Language } \\
\text { - }(\mathrm{ESL})\end{array}$ & $\begin{array}{l}\text { - Mixed methods } \\
\text { - Six ESL teachers } \\
\text { - Questionnaire and semi- } \\
\text { structured interview }\end{array}$ & $\begin{array}{l}\text { - Teacher-centered practices. } \\
\text { - No application of } \\
\text { constructivist strategies. }\end{array}$ & $\begin{array}{l}\text { - Teacher- } \\
\text { centered } \\
\text { learning }\end{array}$ \\
\hline $\begin{array}{l}\text { Bavani et al } \\
(2016)\end{array}$ & - Science & $\begin{array}{l}\text { - Qualitative } \\
\text { - Nine primary teachers } \\
\text { - Interview and observation }\end{array}$ & $\begin{array}{l}\text { - Gave students answers or } \\
\text { conclusion without teaching } \\
\text { them how to analyse. }\end{array}$ & $\begin{array}{l}\text { - Teacher- } \\
\text { centered } \\
\text { learning }\end{array}$ \\
\hline $\begin{array}{l}\text { DeWitt et al } \\
(2016)\end{array}$ & - Science & $\begin{array}{l}\text { - Quantitative } \\
\text { - } 131 \text { secondary teachers } \\
\text { - Questionnaire }\end{array}$ & $\begin{array}{l}\text { - Favoured teaching of facts. } \\
\text { - Preferred giving explanation } \\
\text { to students when learning } \\
\text { concepts. }\end{array}$ & $\begin{array}{l}\text { - Teacher- } \\
\text { centered } \\
\text { learning }\end{array}$ \\
\hline $\begin{array}{l}\text { Abdul et al } \\
\text { (2015) }\end{array}$ & - History & $\begin{array}{l}\text { - Quantitative } \\
\text { - } 76 \text { secondary teachers } \\
\text { - Questionnaire }\end{array}$ & $\begin{array}{l}\text { - Showed low-level use of } \\
\text { HOTS in teaching. }\end{array}$ & - LOTS \\
\hline $\begin{array}{l}\text { Zulhelmi et al } \\
\text { (2017) }\end{array}$ & - Mathematics & $\begin{array}{l}\text { - Quantitative } \\
\text { - } 199 \text { teachers } \\
\text { - Questionnaire } \\
\end{array}$ & $\begin{array}{l}\text { Utilised LOTS even they were } \\
\text { aware of the significance of } \\
\text { HOTS. }\end{array}$ & - LOTS \\
\hline $\begin{array}{l}\text { Mohd et al } \\
\text { (2017) }\end{array}$ & $\begin{array}{l}\text { - Islamic } \\
\text { education }\end{array}$ & $\begin{array}{l}\text { - Quantitative } \\
\text { - } 105 \text { secondary Islamic } \\
\text { education teachers } \\
\text { - Questionnaire } \\
\end{array}$ & $\begin{array}{l}\text { - Asked simple and direct } \\
\text { questions. }\end{array}$ & - LOTS \\
\hline $\begin{array}{l}\text { Azian et al } \\
(2017)\end{array}$ & $\begin{array}{l}\text { - English } \\
\text { Language (ESL) }\end{array}$ & $\begin{array}{l}\text { - Mixed methods } \\
\text { - } 140 \text { secondary teachers } \\
\text { - Questionnaire, observation, } \\
\text { semi-structured interview }\end{array}$ & $\begin{array}{l}\text { - Rarely asked high level } \\
\text { questions. } \\
\text { - The verbs used by teachers } \\
\text { to foster thinking skills were } \\
\text { mostly low level. }\end{array}$ & - LOTS \\
\hline $\begin{array}{l}\text { Khairon et al } \\
\text { (2017) }\end{array}$ & $\begin{array}{l}\text { - English } \\
\text { Language (ESL) }\end{array}$ & $\begin{array}{l}\text { - Mixed methods } \\
\text { - } 12 \text { secondary teachers } \\
\text { - Questionnaire, interview, } \\
\text { and observation }\end{array}$ & $\begin{array}{l}\text { - Applied display questions. } \\
\text { Did not apply HOTS questions } \\
\text { during classroom } \\
\text { observation. }\end{array}$ & - LOTS \\
\hline $\begin{array}{l}\text { Wan \& } \\
\text { Shamilati } \\
(2018)\end{array}$ & $\begin{array}{l}\text { - Malay Language } \\
\text { - Science } \\
\text { - Mathematics }\end{array}$ & $\begin{array}{l}\text { - Qualitative (case study) } \\
\text { - Nine primary teachers } \\
\text { - Observation and interview }\end{array}$ & $\begin{array}{l}\text { - Frequently asked lower order } \\
\text { thinking questions. }\end{array}$ & - LOTS \\
\hline
\end{tabular}

\section{DISCUSSION AND CONCLUSION}

In short, this paper overviews the literature concerning some of the practices in promoting students' development of HOTS during the teaching and learning process. Based on the analysis, the pedagogical practices towards the teaching of HOTS among teachers in Malaysia were classified into two major categories namely practices that 


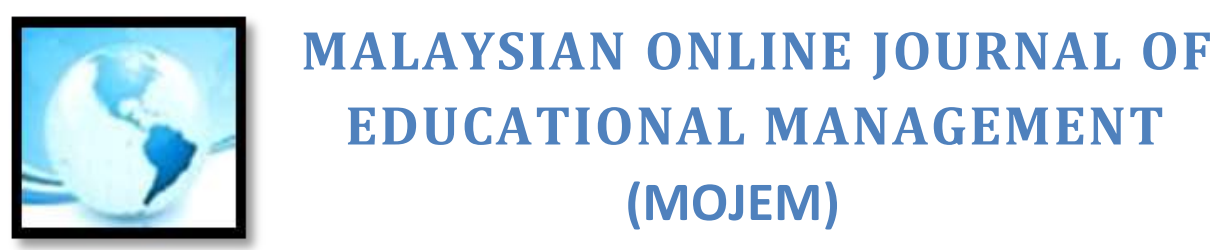

promote and inhibit the teaching of HOTS in classrooms respectively. Collaborative learning, brainstorming, and questioning are among the most highlighted practices used by teachers to promote students' ability to think at a higher level. On the other hand, teacher-centered learning and teaching of lower-order thinking skills (LOTS) are the practices applied by teachers that inhibit the development of HOTS in classrooms. A research outcome (Figure 2) below was presented for the synthesis of the current education policy and the findings regarding teachers' practices in teaching HOTS at Malaysian schools.

Unfortunately, there is a mismatch between the written educational policy and the taught curriculum at schools. Despite the education policy aims to make students critical thinkers, some teachers do not conduct effective teaching of HOTS articulated in the policy (Ministry of Education, 2013). The result shows that the policy on HOTS could not be translated completely into practices because of the differences between the practices shown by teachers in teaching HOTS. Therefore, the achievement of the policy is situated still at a developing extent. The issue may possibly be influenced by a variety of factors including teachers' attitudes, barriers and enablers that teachers face when teaching HOTS in classrooms. Teachers' attitudes towards the teaching of HOTS may potentially affect how they conduct their daily lessons. Teachers who withdraw from promoting students' HOTS may be due to time constraints, heavy syllabus content, students' abilities, and other possible factors. It remains a concern for the researcher to see the gap between the education policy and the classroom practices towards the teaching of HOTS in classrooms.

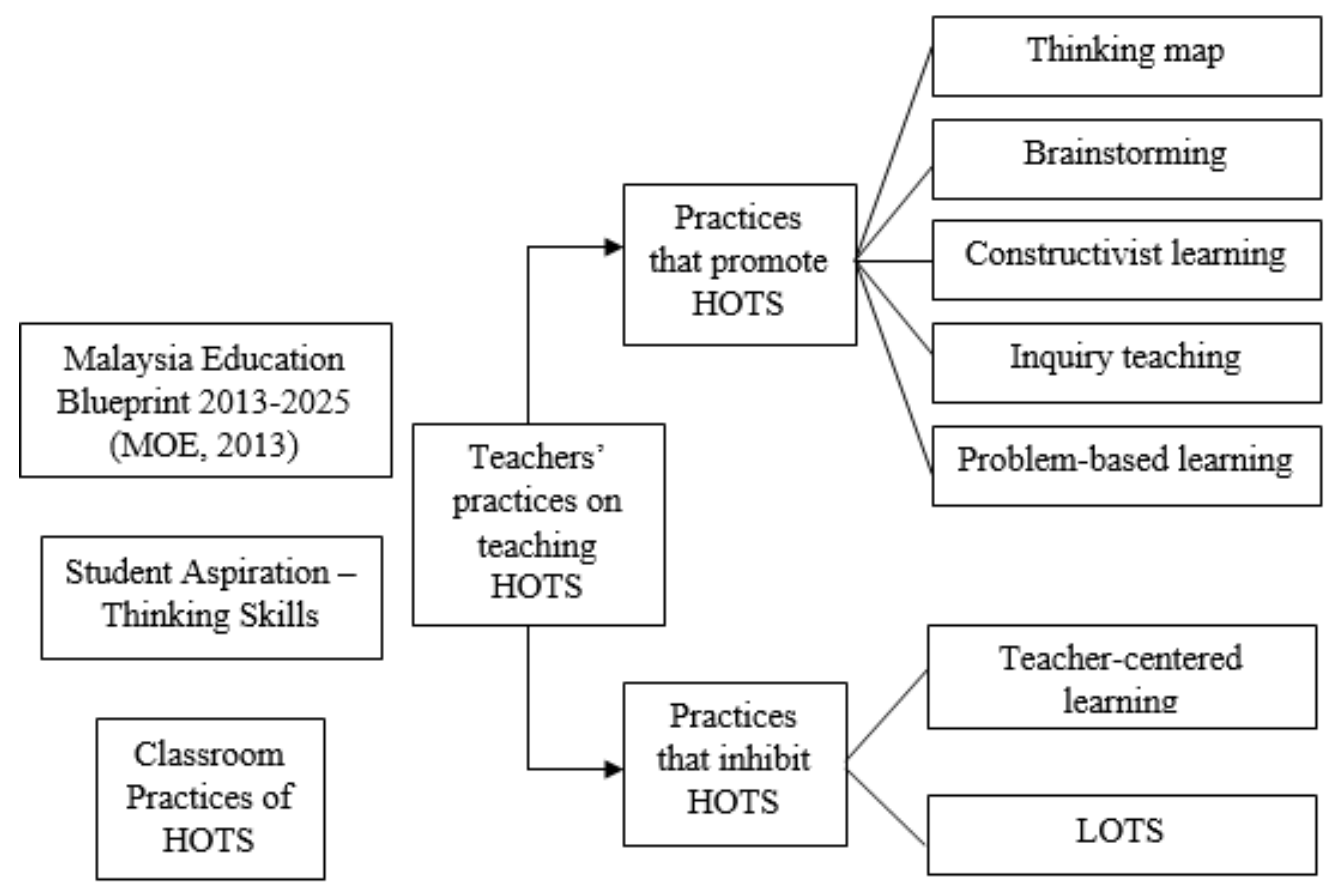

Figure 2. Research Outcome 


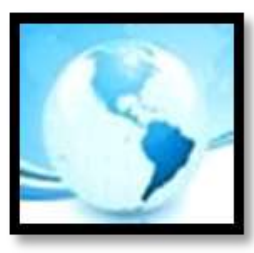

MALAYSIAN ONLINE JOURNAL OF

EDUCATIONAL MANAGEMENT

(MOJEM)

IMPLICATION OF THE FINDING

The main implication of this study was to provide insights on the pedagogical practices in teaching HOTS among teachers in Malaysian education context. Specifically, the findings of the current research are significant to Teacher Training Institutes (Institut Pendidikan Guru), universities that offer teacher training programs, pre-service and inservice teachers, researchers, and other related stakeholders in the field of education. The evidence of this study could enhance our understanding on the current phenomenon of teaching HOTS in classroom context. First and foremost, the findings of this study filled in the knowledge gaps on policy vs practices of teaching HOTS in Malaysian schools. Despite having a clear top-down policy, pedagogical practices carried out by some teachers in Malaysian schools does not promote HOTS. The results suggest that effective teacher is the key to translate policy on HOTS into practices. In other words, having a strong policy on HOTS alone does not necessarily guarantee actual practices in the classrooms. To realize the policy on HOTS, paradigm shift is needed among the teachers so that pedagogical practices implemented at schools are in line with the HOTS policy, as demonstrated by some of the teachers.

This study also shed light on practices that promote HOTS namely problem-based learning, constructivist learning, thinking map, brainstorming, and inquiry teaching were found to be effective in promoting students' HOTS in classrooms. It was found that most of the practices that promote HOTS are multidisciplinary, which can be applied across various disciplines including language, science, mathematics, and other subjects. In other words, teachers from different disciplines can collaborate, share effective classroom practices, and work towards the goal of creating thinking classrooms through the teaching of HOTS. This gives an implication that the findings from this study will provide teacher-training institutes with the real scenarios about classroom practices that teachers use to ensure the teaching of HOTS in their classrooms. It also serves as a basis for the design of more effective and holistic approaches of teaching HOTS, so that the goal of developing students' critical thinkers as stated in the education policy can be achieved.

The findings of this study could serve as a reference for the MOE, Teacher Training Institute (IPG), universities that offer teacher training programs, schools, and related stakeholders to carry out interventions to strengthen teachers' knowledge and skills on HOTS pedagogical practices. Professional training such as in-service courses and workshops on HOTS can also be offered to in-service teachers. In view that attitudes is the key for behavioural change, as proposed by the Theory of Planned Behaviour (Rosenberg and Hovland, 1960), attention should also be given by the Ministry to ensure that teachers have positive attitudes towards the implementation of HOTS in schools. Overall, the current research has significant educational implications as it filled in the knowledge gaps on policy vs practices of HOTS in schools. Findings from the meta-analysis has also provided rich findings and added some interesting areas for future research opportunities.

\section{RECOMMENDATIONS FOR FUTURE RESEARCH}

To conclude, the phenomenon of teaching HOTS in Malaysian education still requires support and encouragement from many important parties such as government, teachers, students, and relevant stakeholders. To overcome the barriers of making all students critical thinkers, the government should consider the design and provision of specific course or preparation programme to teachers so that they get to learn the concept of thinking and the required skills to teach thinking in classrooms (Rosnani, 2003). Besides, it is also suggested that teachers need to consciously learn the effective ways in making changes on the conventional teaching and employing new methodologies to incorporate HOTS into the current Malaysian curriculum (Kho \& Jamalludin, 2015). There is a need for teachers in Malaysia to acquire more knowledge about pedagogical practices related to HOTS so as to deliver highly effective teaching of HOTS in their classrooms.

Next, the analysis shows that there are limited studies done on the teaching of HOTS in relation to other language subjects. For this reason, there is a need to understand the situation wherein how teachers encourage their 


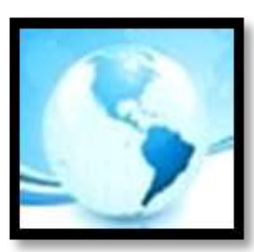

\section{MALAYSIAN ONLINE JOURNAL OF EDUCATIONAL MANAGEMENT (MOJEM)}

students to learn HOTS specifically in Chinese, Malay, and Tamil Language context. It is believed that the discovery might generate some new information whether there is a comparison to the practices used by teachers from other subject matter to teach HOTS during the teaching and learning process. Another finding from the analysis displays that some studies (16.7\%) only applied questionnaire as the sole instrument to investigate teachers' practices in teaching HOTS at Malaysian schools. This poses some disadvantages as in the teachers' responses on the questionnaires might not really reflect their actual practices of teaching HOTS because no qualitative methods such as observation or interview have been done to record what teachers do in their lessons. There is a possibility to see a mismatch between teachers' perception on their practices and teachers' actual practices in classrooms. The inclusion of qualitative methods is crucial because it helps validate teachers' response given in quantitative questionnaire (Wan \& Shamilati, 2018). Therefore, studies should be conducted with a combination of quantitative and qualitative so that the data collected will become highly empirical and more in-depth (Mohd et al., 2017).

The issue of lacking teaching thinking skills could be caused by a range of factors (Li, 2016). By taking this into consideration, further research in this area should include the investigation on teachers' attitudes, barriers, and enablers for teaching HOTS to explore what actually promotes and inhibits teachers' practices in teaching HOTS at Malaysian schools. Additionally, it is still crucial for future researchers to further investigate the pedagogical practices in teaching HOTS demonstrated by teachers particularly in primary education context.

\section{REFERENCES}

Abdul, H. A., Mahani, M., Noor, D. Abd H., Dayana, F. A., Lokman, Mohd. T., \& Umar, H. A. K. (2017). Mathematics teachers' level of knowledge and practice on the implementation of higher-order thinking skills (HOTS). EURASIA Journal of Mathematics Science and Technology Education, 13(1), 3-17. DOI 10.12973/eurasia.2017.00601a

Abdul, T. H., Rosma, O., Azli, A., Norazilawati, A., \& Noraini, M. N. (2015). Teachers' perception on higher order thinking skills as an innovation and its implementation in history teaching. Australian Journal of Basic and Applied Sciences, 9(32), 215-221. Retrieved from https://www.researchgate.net/publication/305767701_Teachers'_Perception_on_Higher_Order_Thinking_ Skills_as_an_Innovation_and_its_Implementation_in_History_Teaching

Ainon, O., Haniff, A. Z., \& Goh, H. S. (2016). Teachers' implementation of the i-think program in the ESL classroom: A case study. International Journal of Science, Arts and Commerce, 1(9), 33-45. Retrieved from www.ijsac.net

Ainon, O., \& Intan, S. M. A. A. (2016). Thinking maps to promote critical thinking through the teaching of literature in the ESL context. Indonesian Journal of English Language Teaching and Applied Linguistics, 1(1), 23-35. Retrieved From http://www.academia.edu/32609479/Thinking_Maps_to_Promote_Critical_Thinking_through_the_Teachin g_of_Literature_in_the_ESL_Context

Arlina, A. Z., \& Melor, M. Y. (2014, February). Strategies used by local ESL teachers in Malaysia to create a constructivist classroom. Paper presented at Symposium of International Language \& Knowledge (SiLK 2014), Penang, Malaysia. Retrieved from https://www.semanticscholar.org/paper/Strategies-Used-ByLocal-ESL-Teachers-in-Malaysia-aZakiYunus/2f6f7f8bc87c919459d2c1ea8c25c713bab69740

Awg Kasmurie Awg Kitot., Abdul Razak Ahmad., \& Ahmad Ali Seman. (2010). The effectiveness of inquiry teaching in enhancing students' critical thinking. Procedia - Social and Behavioral Sciences, 7(C), $264-273$. doi:10.1016/j.sbspro.2010.10.037 


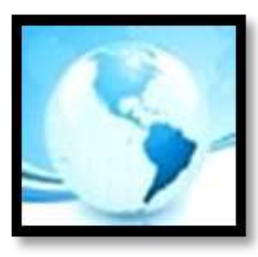

Azian, A. A., Fauziah, I., Noor, M. I., \& Norhanim, A. S. (2017). Investigating the implementation of higher order thinking skills in Malaysian classrooms: Insights from 12 teaching practices. Sains Humanika, 9(4), 65-73. DOI: $10.11113 /$ sh.v9n4-2.1361

Azman, M. Y. (1998, February 25). Implementation of education policy in Malaysia. Retrieved from http://azman97.tripod.com/essay8.html

Bavani, N. R., Selvaranee, S., \& Renuka, V. S. (2016). When students say "I just couldn't think": Challenges in teaching skilful thinking. The Malaysian Online Journal of Educational Sciences, 4(2), 59-69. Retrieved from www.moj-es.net

Brown, H. D. (2007). Principles of language learning and teaching. White Plains, NY: Pearson Education.

Charanjit, K. S. S., Rhashvinder, K. A. S., Tarsame, S. M. S., Nor, A. M., \& Tunku, M. T. M. (2018). Developing a higher order thinking skills module for weak ESL learners. English Language Teaching, 11(7), 86-100. doi: 10.5539/elt.v11n7p86

Chang, D. W., Morshidi, S., \& Dzulkifli, A. R. (2018). Education in Malaysia towards a developed nation (Economics Working Paper No. 2018-4). Retrieved from https://www.iseas.edu.sg/images/pdf/ISEASEWP20184Wan.pdf

Cherry, K. (2019, April 5). Attitude and behavior in psychology. Retrieved from https://www.verywellmind.com/attitudes-how-they-form-change-shape-behavior-2795897

Chew, F. P., \& Shashipriya, N. (2014). Implementation of critical and creative thinking skills in the teaching and learning of literature component in secondary schools. Malay Language Education Journal, 4(2). Retrieved from http://spaj.ukm.my/jpbm/index.php/jpbm/article/viewFile/78/78

Chew, F. P., \& Zul, H. H. (2018). Higher order of thinking skills in teaching and learning Malay language through questioning technique. Malay Language Education Journal, 8(1). Retrieved from http://spaj.ukm.my/jpbm/index.php/jpbm/article/view/161/139

Chiew, Y. D., Anthony, E. M., Berhannudin, M. S., Robijah, K., \& Zulida, A. K. (2016, April). Creating thinking classrooms: perceptions and teaching practices of ESP practitioners. Paper presented at International Conference on Teaching and Learning English as an Additional Language, GlobELT 2016, Antalya, Turkey. doi:10.1016/j.sbspro.2016.10.087

Creswell, J. W. (2012). Educational Research: Planning, conducting, and evaluating quantitative and qualitative research. Boston, MA: Pearson Education.

DeWitt, D., Alias, N., \& Siraj, S. (2016, July). Problem solving strategies of Malaysian secondary school teachers. Paper presented at the Educational Technology World Conference, Bali, Indonesia. Retrieved from http://eprints.um.edu.my/id/eprint/16330

Hanif, H. A. (2017, September 26). Read, count and think critically. New Straits Times. Retrieved from https://www.nst.com.my/opinion/columnists/2017/09/284064/read-count-and-think-critically 


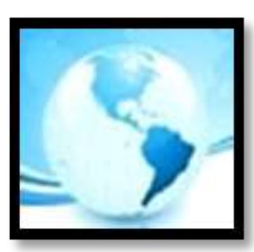

\section{MALAYSIAN ONLINE JOURNAL OF EDUCATIONAL MANAGEMENT (MOJEM)}

Hazlina, A., \& Murniati, A. K. (2018, December 19). No more mid-year, final exams for Year 1 - 3 pupils from 2019. New Straits Times. Retrieved from https://www.nst.com.my/news/nation/2018/12/442165/no-more-midyear-final-exams-year-1-3-pupils-2019

Jalal, A. W. (2017, May 2). Rethinking our education. New Straits Times. Retrieved from https://www.nst.com.my/opinion/columnists/2017/05/235683/rethinking-our-education

Jerome, C., Lee, J. A., \& Ting, S. (2017). What students really need: Instructional strategies that enhance higher order thinking skills (hots) among UNIMAS undergraduates. International Journal of Business and Society, 18(4), 661-668. Retrieved from http://www.ijbs.unimas.my/images/repository/pdf/Vol18-s4-paper2.pdf

Khairon, N. S., Hanita, H., Fauziah, I., \& Azian, A. A. (2017). Incorporating higher order thinking skill (hots) questions in ESL classroom contexts. LSP International Journal, 4(1), 101-116. Retrieved from https://www.researchgate.net/publication/322203189_Incorporating_Higher_Order_Thinking_Skill_HOTS_ Questions_in_ESL_Classroom_Contexts

Kho, P. W., \& Jamalludin, H. (2015, December). An overview of strategies to induce higher order thinking skills and factors hindering it in science teaching. Paper presented at 2nd International Education Postgraduate Seminar, Johor, Malaysia. Retrieved from http://eprints.utm.my/id/eprint/61612/

Li, L. (2016). Integrating thinking skills in foreign language learning: What can we learn from teachers' perspectives? Thinking Skills and Creativity, 22, 273-288. http://dx.doi.org/10.1016/j.tsc.2016.09.008

Maio, G. R., \& Haddock, G. (2010). The psychology of attitudes and attitude change. London: SAGE Publications.

Malini, G., Manjit, M., Sarjit., \& Liew, W. K. (2017). Promoting HOTS via teaching practices. 3L: The Southeast Asian Journal of English Language Studies, 23(1), 75-85. http://doi.org/10.17576/3L-2017-2301-06

Ministry of Education. (2013). Malaysia Education Blueprint 2013-2025 (Preschool to Post Secondary Education), Putrajaya, Malaysia: Ministry of Education, Malaysia. Retrieved from https://www.moe.gov.my/images/dasarkpm/articlefile_file_003108.pdf

Mohd, A. C. N., Mohd, T. A., \& Engku, Z. E. A. R. (2017). Teachers' practice of higher order thinking skills in the lesson of Islamic education. Tinta Artikulasi Membina Ummah, 3(2), 1-13. Retrieved from http://www.journaltamu.com/wp-content/uploads/2018/04/TAMU-Vol-32-December-2017-1.pdf

Mohd, Y. K., Nik, M. R. N. Y., Hamidah, Y. A., \& Kamarulzaman, A. G. (2016). Inculcation of higher order thinking skills (hots) in Arabic language teachingat Malaysian primary schools. Creative Education, 7(2), 307-314. http://dx.doi.org/10.4236/ce.2016.72030

Rahil, M., Zaidatol, A. L. P., Habibah, E., \& Mohd, M. K. (2004). The incorporation of thinking skills in the school curriculum. Kajian Malaysia, 22(2), 23-33. Retrieved from http://web.usm.my/km/22-2-04/01274082_22-204_23-33.pdf

Rajaendram, R. (2018, October 19). Panel to review education policy. The Star. Retrieved from https://www.thestar.com.my/news/nation/2018/10/19/panel-to-review-education-policy-memberstasked-to-come-up-with-ideas-to-improve-curriculum-for-all/

Rajendran, N. S. (2001). The teaching of higher-order thinking skills in Malaysia. Journal of Southeast Asian Education, 2(1), 1-21. Retrieved from http://nsrajendran.tripod.com/Papers/asiapacificjournal.pdf 


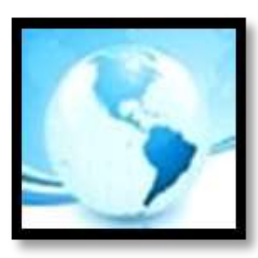

\section{MALAYSIAN ONLINE JOURNAL OF EDUCATIONAL MANAGEMENT (MOJEM)}

Rajendran, N. S. (2008). Teaching and acquiring higher order thinking skills: Theory and practice. Perak, Malaysia: Percetakan Zainon Kassim.

Rosenberg, M. J., \& Hovland, C. I. (1960). Cognitive, affective and behavioural components of attitudes. In C. I. Hovland \& M. J. Rosenberg (Ed.), Attitude organization and change: An analysis of consistency among attitude components (pp. 112-163). New Haven: Yale University Press.

Rosnani, H. (2003). Malaysian's teachers attitude, competency and practices in the teaching of thinking. International Islamic University Malaysia, 11(1), 27-50. Retrieved from

http://journals.iium.edu.my/intdiscourse/index.php/islam/article/view/245

Sandhya, M., \& Sheila, S. P. (2018, November 1). No exams for lower primary. The Star. Retrieved from https://www.thestar.com.my/news/nation/2018/11/01/no-exams-for-lower-primary-maszlee-it-will-bereplaced-with-more-objective-assessments/

Siti, N. A. (2012). Malaysian polytechnic lecturers' teaching practices with ICT utilization to promote higher-order thinking skills. (Doctoral thesis, lowa State University, Ames, lowa). Retrieved from https://lib.dr.iastate.edu/etd

Sivapakkiam, R., Fadzilah, A. R., Habsah, I., Umi, K. A. M., \& Rozita, R. S. (2016). Teachers' levels of knowledge and interest on higher order thinking skills (HOTS) according to the field taught and category of schools. Journal of Modern Education Review, 6(9), 611-621. Retrieved from http://www.academicstar.us

Soo, K. Y., Nor, H. H., Rohani, J., \& Siti, N. M. K. (2015). Innovating with HOTS for the ESL reading class. English Language Teaching, 8(8), 10-17. doi:10.5539/elt.v8n8p10

Tajularipin, S., Vickneswary, M., Diwiyah, M., Raidah, H., \& Suzieleez, S. A. R. (2017). Implementation of higher order thinking skills in teaching for science: A case study in Malaysia. International Research Journal of Education and Sciences, 1(1), 1-3. Retrieved from http://www.masree.info/wpcontent/uploads/2017/02/20170226-IRJES-VOL-1-ISSUE-1-FULL-2017.pdf\#page=7

Tan, Y. P., \& Mohammad, Y. A. (2014). Teacher and student questions: A case study in Malaysian secondary school problem-based learning. Asian Social Science, 10(4), 174-182. doi:10.5539/ass.v10n4p174

Tang, K. N., \& Tan, C. C. (2015, May). The importance of ethics, moral and professional skills of novice teachers. Paper presented at 6th World conference on Psychology Counseling and Guidance, Antalya, Turkey. doi: 10.1016/j.sbspro.2015.09.004

The HEAD Foundation. (2019). Educational Policy in Malaysia - Implementation Challenges and Policy Proposals. Retrieved from https://www.nottingham.edu.my/Education/documents/education-leadership- conference/ The-HEAD-Foundation-Policy-Brief-No.-7-Educational-Policy-in-Malaysia-Implementation Challenges-andPolicy-Proposals-Feb.pdf

United Nations, Educational, Scientific and Cultural Organization. (2013). Malaysia Education Policy Review. Retrieved from https://unesdoc.unesco.org/ark:/48223/pf0000221132

Viennet, R., \& Pont, B. (2017). Education policy implementation: A literature review and proposed framework. (OECD Education Working Paper No. 162). France: OECD Education. Retrieved from 


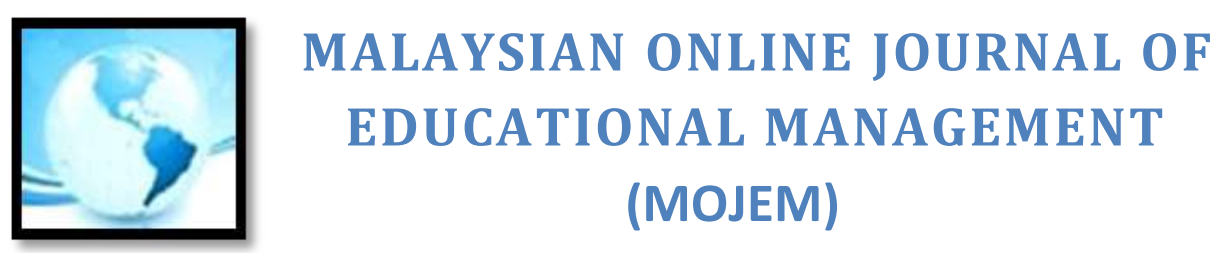

http://www.oecd.org/officialdocuments/publicdisplaydocumentpdf/?cote=EDU/WKP(2017)11\&docLanguag $\mathrm{e}=\mathrm{En}$

Wan, M. W. Y., \& Shamilati, C. S. (2018). Teachers' knowledge of higher order thinking and questioning skills: a case study at a primary school in Terengganu, Malaysia. International Journal of Academic Research in Progressive Education and Development, 7(2), 45-63. DOI: 10.6007/IJARPED/v7-i2/4120

Zainudin, H., Jayalatchmee, M., Lokman, T., Rohaya, T., Sanitah, M. Y., \& Noor, A. A. (2018, December). The 21st century learning in malaysian primary school: Exploring teachers' understanding and implementation of HOTS. In 1st International Conference on Creativity, Innovation and Technology in Education (IC-CITE 2018). Atlantis Press.

Zaleha, I., Leong, C. Y., \& Shiau, W. C. (2016). Perceptions of critical thinking inteaching mathematics among preservice teachers. In Zaleha, I., \& Mohaini, M. (Eds.), Contemporary approaches in teaching and learning Mathematics (pp. 57-72). Retrieved https://www.researchgate.net/profile/Shiau_Wei_Chan2/publication/305639263_Perceptions_of_Critical_ Thinking_in_Teaching_Mathematics_among_Preservice_Teachers/links/5796fe5e08ae33e89fad913c/Perce ptions-of-Critical-Thinking-in-Teaching-Mathematics-among-Pre-service-Teachers.pdf

Zulhelmi, Z., Abdu, H. A., \& Noor, A. A. (2017). The Rasch analysis of mathematics teachers' practices on teaching thinking skills. Man In India, 97(19), 141-152. Retrieved from https://www.researchgate.net/profile/Abdul_Abdullah10/publication/320602092_The_Rasch_analysis_of_ mathematics_teachers\%27_practices_on_teaching_thinking_skills/links/59efe3e7aca272a2500132fe/TheRasch-analysis-of-mathematics-teachers-practices-on-teaching-thinking-skills.pdf

Zuraina, A. (2009). A case study on collaborative learning to promote higher thinking skills (HOTS) among English as a second language (ESL) learners, UMP Journal: Social Sciences and Technology Management, 1(1), 23-38. Retrieved from http://umpir.ump.edu.my/id/eprint/5069/1/pbmsk-2009-zuraina-CaseStudyOn.pdf 